\title{
REFLECTION ON SPATIAL VISUALIZATION FOR ENHANCED LEARNING - A COMPREHENSIVE REVIEW
}

\author{
P. SRINIVASA RAO ${ }^{* 1}$, G V S S. SHARMA ${ }^{2} \&$ B. SURENDRA BABU ${ }^{3}$ \\ ${ }^{I}$ Mechanical Engineering Department, Centurion University of Technology and Management, Odisha, India \\ ${ }^{2}$ Mechanical Engineering Department, GMR Institute of Technology, Rajam, India \\ ${ }^{3}$ Mechanical Engineering Department, GITAM Institute of Technology, Visakhapatnam, India
}

\begin{abstract}
The purpose of this review is to consolidate and comprehend the different works carried out in the domain of spatial visualization and its varied applications in pedagogy and education pertaining to engineering as well as medicine education. Diversified domains have been identified like schooling, engineering learning, pedagogy, industrial applications, medical pedagogy and product design. The progress in the field of spatial visualization pertaining to the above identified domains has been captured by extracting the information from the published works in the related spheres. This work gives an up to date access to the different facets of spatial visualization for enhanced learning at all ages of students ranging from schooling to graduation and serves as a ready reference to reviewers, editors and various prospective authors. This work integrates all the recent works in spatial visualization, their application in teachinglearning process and other domains

KEYWORDS: Spatial Visualization (SV), Pedagogy, Computer Aided Design (CAD), Geometric Modelling \& Industrial Applications
\end{abstract}

Received: Jun 01, 2020; Accepted: Jun 20, 2020; Published: Jun 29, 2020; Paper Id.: IJMPERDJUN2020119

\section{INTRODUCTION}

When an object is oriented in different angles and directions, the ability to recognize and perceive the similarities in the object is spatial visualization (SV). Prominent aspect of spatial visualization is spatial imagination wherein the observer is expected to foresee and imagine the non-existent views of the object. It encompasses visualizing and imagining the different views of the object from given direction, without orienting the object in that desired direction.

Spatial visualization in itself a separate field when compared to general intelligence. With better spatial visualization capability, the fine motor skills like dexterity of hands, playing better game of football or hockey is possible. During the driving of a vehicle, judging the closeness or magnanimity of objects and direction of motion of other vehicles is largely affected by the ability of spatial visualization. A prominent aspect of visualization is that it can be improved upon practice.

This work consolidates and summarizes a broad spectrum of enhanced learning through spatial visualization in the domains of early schooling, engineering education, pedagogy, industrial applications and teaching of medicine.

\section{Spatial Visualization in Early Schooling}

Spatial visualization helps children of early age in perceiving their other subjects during their schooling. Humphreys 
et al. [1] carried out an in-depth study of how spatial-math ability has an edge over the verbal-math ability. Dixon [2] concluded that the students exposed to dynamic instructional environment through spatial reflection and rotation concepts, outperformed the students experiencing traditional instruction environment. Mack [3] in his Doctoral thesis proved that adolescents receiving instructions in Computer Aided Design (CAD) showed improvement in spatial visualization ability when compared to the subjects not receiving CAD instructions. Christou et al. [4] developed software applications for improving the spatial visualization skills of elementary and lower secondary students. Fennema and Tartre [5] experimented on application of spatial visualization among higher secondary school mathematics students. Guven and Kosa [6] examined the effect of spatial visualization in the field of mathematics and found that computer aided geometry software supported and enhanced the students' SV skills.

Newcombe and Shipley [7] devised an assessment instrument consisting of SV tests for children and affirmed that spatial training effects are more marked when children are younger. Rafi et al. [8] performed an experimental study involving thirtythree secondary school students in SV training. They observed a noticeable improvement in the students when trained in SV skills when compared to conventional methods. Rafi et al. [9] performed experiments using a Web-based Virtual Environment on teachers' spatial ability understanding for teaching engineering drawing for secondary school subjects in Malaysia. Gilbert et al. [10] focused on the research of how modelling activities can foster students' acquisition of metavisualization skills, in the domain of ionic bonding while learning chemistry. Turgut and Nagy-Kondor [11] investigated the influence of SV skills on Mathematics teachers and recorded some significant influence of mathematics teaching and learning with the help of Heinrich spatial visualization tests. Dori and Kaberman [12] assessed the studying of chemistry in a computerized Molecular Modeling learining environment through SV. This has led to subsequent increasing in the scores in the subject. Cherney and Voyer [13] formulated a questionnaire for examining the role of activities preference in spatial performance. Cantürk-Günhan et al. [14] examined the spatial ability of mathematics teachers and concluded that teachers should use appropriate geometric materials in mathematics lessons for better understanding of the students.

Thus, at early age of schooling, SV skills play a tremendous impact on the development of the children. Through SV skills they can develop a complete understanding of all subjects, leading to a holistic development.

\section{Learning Effects of Spatial Visualization among Engineering Students}

Spatial visualization helps adolescents and adults in perceiving their subjects during their graduation in engineering courses. Akasah and Alias [15] attempted to bridge the SV skills gap between novice and experts of civil engineering students by taking the engineering drawing skills into consideration. Gorska [16] of Cracow university of Technology performed a longitudinal research on spatial ability of engineering students. Marunic and Glazar [17] studied applications of SV onto the engineering course and confirmed that success of engineering education largely depends on enhanced spatial visualization ability. SV through 3-D construction models in civil engineering were used by Glick et al. [18]. They found that students exposed to spatially visualized computer-aided models performed better in the field work. Blasko and Holliday-Darr [19] showed that spatial training for mechanical engineering and plastic engineering technology students, has improved their overall grade-point-average (GPA) in a short time-span of a single semester. Yaomin Dong [20] proved that ability to visualize in 3 dimensions through engineering graphics improves students success and retention. Sorby [21] at Michigan Technological University aimed at improving 3D spatial skills of engineering students which in-turn helps them in improving their grades and retention rates. Gerson et al. [22] studied the effect of multimedia software for development of 3D spatial skills for engineering students to see things that are difficult to demonstrate in the classroom. Olkun [23] took engineering 
drawing activities as the platform for realizing improvement in the SV abilities among the engineering students. Wang et al. [24] studied the influence of web based 2D and 3D interactions on the spatial visualization ability of undergraduate students. Hence it can be inferred that SV skills have a profound learning effect among the engineering students. Through SV they tend to unfold the difficult concepts and assimilate the concept by thoroughly understanding them.

\section{Engineering Pedagogy through Spatial Visualization}

Spatial visualization and its effect on pedagogy, for better teaching skill set is discussed here. Hsi, Linn and Bell [25] proved that spatial reasoning and visualization plays a prominent role in engineering education. Sorby and Baartmans [26] studied the improvement of 3D spatial visualization skills among women engineering students. Esche et al. [27] experimented with the applications of Augmented Reality for improvement of spatial cognition, concept learning and decision making through interactive learning among the engineering students. Sorby [28] of Michigan Technological University stressed on the importance of 3-D SV skills in the domain of engineering design graphics education. Uttal et al. [29] concluded through their observations that enrichment in spatial skills enhances understanding in the fields of STEM. Adebayo et al. [30] at Cornell University strived for the improvement in the spatial visualization thinking of the freshmen engineering students entering newly into the engineering program.

Farrar et al. [31] proved that students can use learned skills and mastery of SV to interpret and analyze visuals in future engineering work. Sorby and Baartmans [32] studied on developing 3-D spatial visualization skills among the first year engineering students. They proved that students improved on SV skills leading to higher retention rates in the engineering programs. Garmendia et al. [33] defined a set of skills which guides the first year engineering students to spatially visualise the engineering parts and excel in their course work. Fouh et al. [34] discussed about visualization in computer science education and explained that static media such as text and images can better be assimilated by the students through SV. Martín-Gutiérrez et al. [35] used computer vision techniques and augmented reality for imparting training in spatial visualization to engineering students. Samsudin et al. [36] studied the impact of SV skills in drawing orthographic projections among engineering students. Ferguson et al. [37] studied the effects of mechanical dissection manupulatives on improving the SV ability of freshmen at Western Carolina University. Contero et al. [38] analysed the importance of SV skills with a dual approach of computer graphics and sketch based modelling among the engineering students. Chun-Heng Ho et al. [39] investigated 2D and 3D spatial and mathematical abilities among the students of Georgia Institute of Technology and came to a conclusion that performance on $2 \mathrm{D}$ and 3D spatial tasks were consistently correlated. Martín-Gutiérrez et al. [40] presented an application of augmented reality for improving spatial abilities of engineering students.

Scribner and Anderson [41] supported the fact that educators in technical education should incorporate instructional methods that address modality learning styles when teaching SV. Martín-Dorta et al. [42] performed a pilot study to evaluate the feasibility of launching a course based on 3D CAD modelling for improved spatial abilities of engineering students. Gilbert [43] affirmed that metacognitive ability in respect of visualization, which he termed as "metavisual capability", is required for undertaking complex engineering and science tasks in education. Branoff and Dobelis [44] researched on relationship that exists between reading engineering drawing and SV ability, and found that SV ability played a significant role in how well the students visualized the part geometry. Ault and John [45] proved that training enhanced visualization skills among the first year engineering students at the Polytechnic of Namibia. Yue [46] recorded an enhanced performance on SV test with realistic 3D views among college students. Connolly [47] at Purdue University integrated the SV in the regular curriculum for the benefit of the student community and concluded that research in SV area must be continued for 
better teaching and learning to happen. Tsai and Yen [48] of Taiwan reached to a conclusion in their research that Kinect sensor assisted learning system not only could promote in developing the students' SV skills, but also encourage them to become active learners. Connolly et al.[49] measured and enhanced SV skills in engineering students at Purdue University to better solve real world engineering design problems. Cohen and Hegarty [50] developed and administered a new online spatial test that assesses the ability to identify the two-dimensional cross section of a three-dimensional geometric solid, a skill that is important in many STEM disciplines, including biological and medical sciences, geology, engineering and mathematics.

Martín-Gutiérrez et al. [51] concluded that spatial skills through augmented reality improved the scores and reduced the drop out in engineering education at a Spanish University. Results showed that augmented reality had a positive effect on the users who wanted to improve their spatial skills. Richards et al. [52] told that the method of "learning how to learn" is the technique for retention of spatial memory among the students. Bishop [53] fostered the fact that spatial abilities play a very important role in mathematics education. Katsioloudis et al. [54] found that the 3D printed solid model and 3D computer software model both provided statistically significant higher scores than 2D drawings while teaching the Industrial Technology students. Yue and Chen [55] reaffirmed that through Purdue Spatial Visualization Tets-Rotation, the SV abilities of engineering students. Thornton et al. [56] proved that there exists a potential for augmented Reality not only in STEM education, but across all disciplines. Gorska [57] was instrumental in developing a new spatial imagination test TPS (Test Priestorovej Priedstavivosti) to increase the levels of spatial skills of engineering students.

David [58] confirmed that students low in spatial abilities gained most from the training imparted to them on mental rotation, spatial orientation and spatial visualization. Neubauer et al. [59] studied the combined effect of a mental rotation training on 2D and 3D tasks on 38 male and 39 female adolescents and observed a complex sex, dimensionality, training and brain hemisphere interaction. Dunser et al. [60] employed Virtual reality as a spatial ability training tool. Chester [61] of Griffith University proposed pedagogical strategies for enabling the novice students to produce 3D-CAD models. It is argued that 3D-CAD must become a part and parcel of curriculum in the schools in order to enhance the teaching strategies. Schonborn and Anderson [62] examined the curriculum of biochemistry and concluded that visual literacy is the basis for conceptual understanding in this field. Gorska and Juscakova [63] studied the spatial visualization abilities of Polish and Slovakia engineering students, based on Space Imagination test. Sharma and Dumpala [64] facilitated the classroom teaching through visualization by three-dimensional software geometric models and stressed on the fact that SV skills can be honed upon constant practice. Thus, for better understanding and assimilation of concepts by students, a teacher should embrace the SV skills.

\section{Industrial Applications of Spatial Visualization}

Spatial visualization ability (or skill) plays a prominent role especially in engineering and architecture. Spatial visualization has noticeable impact on solving technical related engineering problems and issues. Koch [65] in his dissertation investigated the effects of solid modelling and visualization on technical problem solving. The students were subjected to Purdue SpatialVisualization Test / Visualization of Rotations (PSVT/TR) and results revealed that spatial visualization was a better predictor of success in technical problem solving. Downing et al. [66] researched upon the effects and interaction of spatial visualization on information seeking in today's era of information technology. Oman et al. [67] studied the effect of spatial orientation on astronauts training program. King [68] of university of Plymouth studied on the influence of spatial literacy in geography, earth and environmental sciences (GEES) and concluded that spatial skills form an important aspect in the 
Earth sciences. Teyseyre and Campo [69] studied visual representations, interaction issues, evaluation methods and development tools in software technology. Sharma et al. [70] devised a spatial visualization methodology for brainstorming the causal factors for process deviations in product manufacturing processes.

Aesthetics, styling, in real time product design calls for a high degree of spatial visualization. Corrie van der Lelie [71] studied about visualization through storyboards in the product design process. Herter et al. [72] focussed on cognitive aspects of perception and understanding in virtual reality research through spatial visualization of conceptual models. Shah et al. [73] developed standardized tests for a better product design through divergent thinking, visual thinking and spatial reasoning. In engineering especially in the area of product design, the designer is expected to exhibit higher levels of visualization. Similarly the architect spatially imagines the different views of engineering constructions in 3-point perspective comprising of 3 dimensions of length, breadth and height.

\section{Applications of Spatial Visualization in Teaching of Medicine}

Wanzel et al. [74] examined the influence of visual-spatial ability and manual dexterity on surgical performance in the medical field. Jones and Broadwell [75] explained how students with little or no vision access to visual representations. Passig and Eden [76] proved that the rotating virtual reality (VR) and three-dimensional (3D) objects have a positive effect on the ability of deaf and hard-of-hearing children. Brewer et al. [77] reinforced the fact that in neuroanatomy of medicine, SV can help in learning the complicated spatial relation between the numerous discrete structures of the brain anatomy. Friedl et al. [78] developed a virtual model of heart through virtual reality and trained the medical students for performing operations on the model through interactive virtual reality. Silen et al. [79] threw light on application of 3D visualizations in learning anatomy and physiology in medical field. They could achieve success by implementing 3D images in already existing themes in educational programs. Keehner et al. [80] emphasized on the importance of spatial skills in performing laparoscopic surgeries. Their findings supported the use of virtual environments in improving SV skills which are required for surgical trainings. Nguyen et al. [81] explored the influence of spatial visualization ability in the anatomy comprehension in medical education. Petersson et al. [82] Confirmed that three-dimensional visualization through virtual reality proves to be an effective learning of anatomy in medical applications.

Thus, medical applications calls for expertise in SV skills for better performance of surgeries and also for better diagnosis. The SV skills combined with virtual reality proves to be an effective and efficient tool in the world of teaching medical sciences.

Table 1 summarizes the various aspects of literature reviewed in this work. Figure 1 shows the percentage contribution in the form of a pie chart, of the various application areas of spatial visualization reviewed in this work. It is clearly evident that the major portion of the pie chart constitutes of the pedagogical applications in the field of spatial visualization reviewed in this work.

\section{CONCLUSIONS}

Spatial visualization can be a powerful tool for improving the imagination skills among the engineering students and working professionals of engineering. It also finds widespread application among the architects. In the field of product design, spatial visualization helps in improving the aesthetics of the product. In the industrial field SV skills play an important role as a problem solving tool. Thus, spatial visualization helps in almost all walks of life and can be improved upon constant practice. At the outset, irrespective of the age and field of activity, spatial visualization cuts across the borders and finds widespread 
applications in the fields of pedagogy and schooling, engineering, architecture, medicine, product design and industry. The further scope of works is projected for improving of the spatial visualization skills for the hearing impaired in order to improve their quality of living and making them more employable.

Table 1: Table Label

\begin{tabular}{|c|c|c|c|c|c|c|c|}
\hline No. & Authors (in chronological order) & : & 我 & 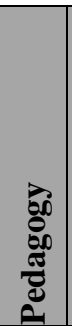 & 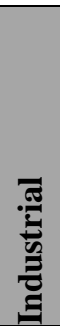 & 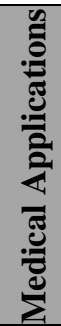 & 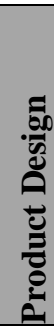 \\
\hline 1 & E. Fennema and L. A. Tartre (1985) & $\sqrt{ }$ & & & & & \\
\hline 2 & W. E. Mack (1992) & $\checkmark$ & & & & & \\
\hline 3 & L. G. Humphreys et al. (1993) & $\checkmark$ & & & & & \\
\hline 4 & J. K. Dixon (1995) & $\checkmark$ & & & & & \\
\hline 5 & S. A. Sorby \& B. J.B aartmans (1996) & & & $\checkmark$ & & & \\
\hline 6 & S. Hsi et al. (1997) & & & $\checkmark$ & & & \\
\hline 7 & S. A. Sorby \& B. J. Baartmans (2000) & & & $\checkmark$ & & & \\
\hline 8 & C. M. Oman et al. (2000) & & & & $\sqrt{ }$ & & \\
\hline 9 & D. Passig and S. Eden (2000) & & & & & $\sqrt{ }$ & \\
\hline 10 & H. B. Gerson et al. (2001) & & $\checkmark$ & & & & \\
\hline 11 & J. Yue and D. M. Chen (2001) & & & $\checkmark$ & & & \\
\hline 12 & J. T. Richards et al. (2002) & & & $\checkmark$ & & & \\
\hline 13 & M. Reinhard Friedl (2002) & & & & & $\checkmark$ & \\
\hline 14 & S. Olkun et al. (2003) & & $\checkmark$ & & & & \\
\hline 15 & R. A. Górska and Z. Juscakova (2003) & & & $\checkmark$ & & & \\
\hline 16 & K. R. Wanzel et al. (2003) & & & & & $\checkmark$ & \\
\hline 17 & A. Rafi et al. (2005) & $\checkmark$ & & & & & \\
\hline 18 & R. Gorska (2005) & & $\checkmark$ & & & & \\
\hline 19 & S. A. Scribner and M. A. Anderson (2005) & & & $\checkmark$ & & & \\
\hline 20 & J. K. Gilbert (2005) & & & $\checkmark$ & & & \\
\hline 21 & R. A. Górska (2005) & & & $\checkmark$ & & & \\
\hline 22 & R. E. Downing et al. (2005) & & & & $\checkmark$ & & \\
\hline 23 & M. Contero (2006) & & & $\checkmark$ & & & \\
\hline 24 & Chun-Heng Ho et al. (2006) & & & $\checkmark$ & & & \\
\hline 25 & A. Dünser, et al. (2006) & & & $\checkmark$ & & & \\
\hline 26 & D. S. Koch (2006) & & & & $\checkmark$ & & \\
\hline 27 & H. King (2006) & & & & $\checkmark$ & & \\
\hline 28 & C. Van der Lelie (2006) & & & & & & $\checkmark$ \\
\hline 29 & M. Keehner et al. (2006) & & & & & $\checkmark$ & \\
\hline 30 & C. Christou, et al. (2007) & $\checkmark$ & & & & & \\
\hline 31 & S. A. Sorby (2007) & & $\checkmark$ & & & & \\
\hline 32 & H.-C. Wang et al. (2007) & & $\checkmark$ & & & & \\
\hline 33 & M. Garmendia et al. (2007) & & & $\checkmark$ & & & \\
\hline 34 & B. Güven and T. Kosa (2008) & $\checkmark$ & & & & & \\
\hline 35 & A. Rafi et al. (2008) & $\checkmark$ & & & & & \\
\hline 36 & C. W. Ferguson et al. (2008) & & & $\checkmark$ & & & \\
\hline 37 & N. Martín-Dorta (2008) & & & $\checkmark$ & & & \\
\hline 38 & I. Chester (2008) & & & $\checkmark$ & & & \\
\hline 39 & M. G. Jones and B. Broadwell (2008) & & & & & $\checkmark$ & \\
\hline 40 & C. Silén et al. (2008) & & & & & $\checkmark$ & \\
\hline 41 & B. Cantürk-Günhan et al. (2009) & $\checkmark$ & & & & & \\
\hline 42 & S. A. Sorby (2009) & & & $\checkmark$ & & & \\
\hline 43 & J. Yue (2009) & & & $\checkmark$ & & & \\
\hline 44 & P. E. Connolly (2009) & & & $\checkmark$ & & & \\
\hline 45 & P. Connolly and M. Sadowski (2009) & & & $\checkmark$ & & & \\
\hline
\end{tabular}




\begin{tabular}{|l|l|l|l|l|l|l|l|}
\hline 46 & B. Sriraman et al. (2009) & & & $\checkmark$ & & & \\
\hline 47 & A. R. Teyseyre and M. R. Campo (2009) & & & & $\checkmark$ & & \\
\hline 48 & J. Shah et al. (2009) & & & & & & $\checkmark$ \\
\hline 49 & H. Petersson et al. (2009) & & & & & $\checkmark$ & \\
\hline 50 & J. K. Gilbert et al. (2010) & $\checkmark$ & & & & & \\
\hline 51 & I. D. Cherney and D. Voyer (2010) & $\checkmark$ & & & & & \\
\hline 52 & Z. Akasah and M. Alias (2010) & & $\checkmark$ & & & & \\
\hline 53 & D. Blasko and K. Holliday-Darr (2010) & & $\checkmark$ & & & & \\
\hline 54 & J. Martín-Gutiérrez et al. (2010) & & & $\checkmark$ & & & \\
\hline 55 & H. K. Ault and S. John (2010) & & & $\checkmark$ & & & \\
\hline 56 & A. C. Neubauer et al. (2010) & & & $\checkmark$ & & & \\
\hline 57 & K. J. Schönborn and T. R. Anderson (2010) & & & $\checkmark$ & & & \\
\hline 58 & K. A. Samsudin et al. (2011) & & & $\checkmark$ & & & \\
\hline 59 & J. Martín-Gutiérrez et al. (2011) & & & $\checkmark$ & & & \\
\hline 60 & Y. J. Dori and Z. Kaberman (2012) & $\checkmark$ & & & & & \\
\hline 61 & S. Glick et al. (2012) & & $\checkmark$ & & & & \\
\hline 62 & Y. Dong (2012) & & $\checkmark$ & & & & \\
\hline 63 & E. Fouh et al. (2012) & & & $\checkmark$ & & & \\
\hline 64 & C. A. Cohen and M. Hegarty (2012) & & & $\checkmark$ & & & \\
\hline 65 & T. Thornton, et al. (2012) & & & $\checkmark$ & & & \\
\hline 66 & L. T. David (2012) & & & $\checkmark$ & & & \\
\hline 67 & D. N. Brewer et al. (2012) & & & & & $\checkmark$ & \\
\hline 68 & N. Nguyen et al. (2012) & & & & & $\checkmark$ & \\
\hline 69 & S. K. Esche (2013) & & & $\checkmark$ & & & \\
\hline 70 & D. H. Uttal et al. (2013) & & & $\checkmark$ & & & \\
\hline 71 & E. J. Farrar et al. (2013) & & & $\checkmark$ & & & \\
\hline 72 & T. Branoff and M. Dobelis (2013) & & & $\checkmark$ & & & \\
\hline 73 & C.-H. Tsai and J.-C. Yen (2013) & & & $\checkmark$ & & & \\
\hline 74 & J. Herter (2013) & & & & & & $\checkmark$ \\
\hline 75 & G. Marunić and V. Glažar (2014) & & $\checkmark$ & & & & \\
\hline 76 & O. O. Adebayo et al. (2014) & & & $\checkmark$ & & & \\
\hline 77 & P. Katsioloudis et al. (2014) & & & $\checkmark$ & & & \\
\hline 78 & Newcombe and Shipley (2015) & $\checkmark$ & & & & & \\
\hline 79 & Turgut and R. Nagy-Kondor (2015) & $\checkmark$ & & & & & \\
\hline 80 & J. Martín-Gutiérrez et al. (2015) & & & $\checkmark$ & & & \\
\hline 81 & G. Sharma and R. Dumpala (2015) & & & $\checkmark$ & & & \\
\hline 82 & G. Sharma et al. (2016) & & & & $\checkmark$ & & \\
\hline & & & & & \\
\hline
\end{tabular}

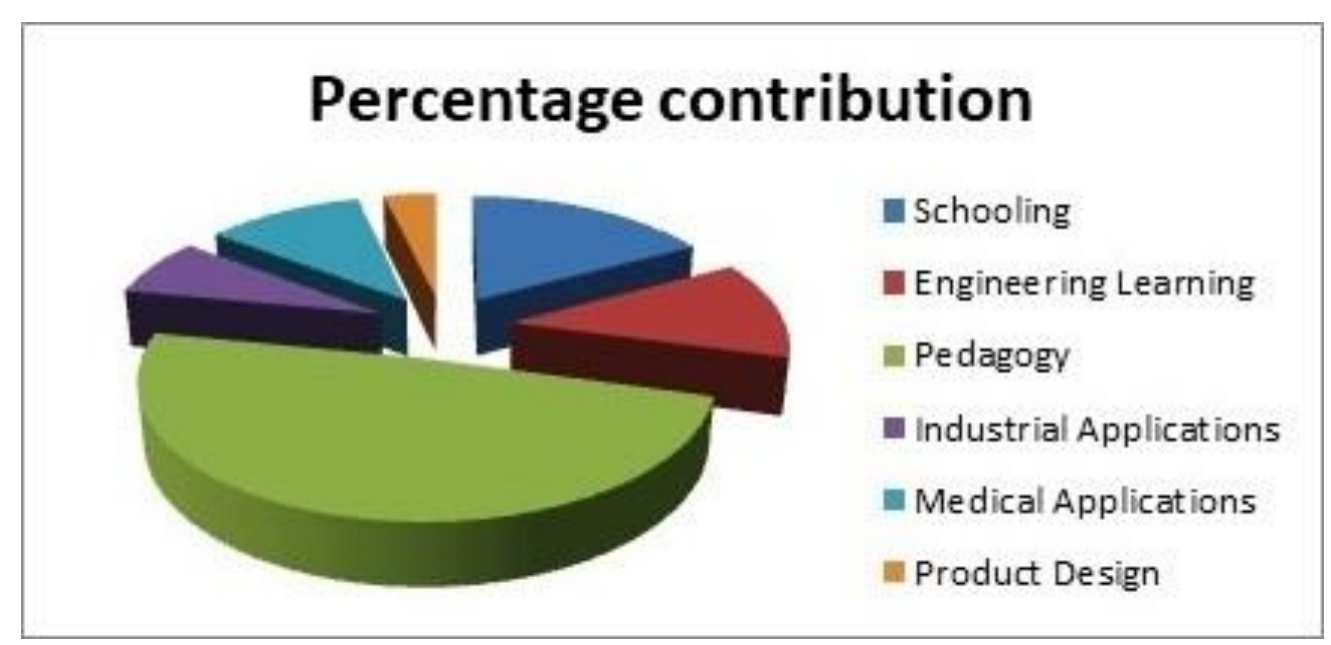

Figure 1: Percentage Contribution of Various Areas Reviewed in this Work

\section{REFERENCES}

1. L. G. Humphreys, D. Lubinski, and G. Yao, "Utility of predicting group membership and the role of spatial visualization in 
becoming an engineer, physical scientist, or artist," Journal of Applied Psychology, vol. 78, p. 250, 1993.

2. J. K. Dixon, "Limited English proficiency and spatial visualization in middle school students' construction of the concepts of reflection and rotation," Bilingual Research Journal, vol. 19, pp. 221-247, 1995.

3. W. E. Mack, "The effect of training in computer-aided design on the spatial visualization ability in selected gifted adolescents," Virginia Tech, 1992.

4. C. Christou, K. Jones, D. Pitta, M. Pittalis, N. Mousoulides, and P. Boytchev, "Developing student spatial ability with 3 dimensional applications," Retrieved July, vol. 30, p. 2014, 2007.

5. E. Fennema and L. A. Tartre, "The use of spatial visualization in mathematics by girls and boys," Journal for Research in Mathematics Education, pp. 184-206, 1985.

6. B. Güven and T. Kosa, "The effect of dynamic geometry software on student mathematics teachers' spatial visualization skills," Turkish Online Journal of Educational Technology-TOJET, vol. 7, pp. 100-107, 2008.

7. N. S. Newcombe and T. F. Shipley, "Thinking about spatial thinking: New typology, new assessments," in Studying visual and spatial reasoning for design creativity, ed: Springer, 2015, pp. 179-192.

8. A. Rafi, K. A. Samsudin, and C. S. Said, "Training in spatial visualization: The effects of training method and gender," Educational Technology \& Society, vol. 11, pp. 127-140, 2008.

9. A. Rafi, K. Anuar, A. Samad, M. Hayati, and M. Mahadzir, "Improving spatial ability using a Web-based Virtual Environment (WbVE)," Automation in construction, vol. 14, pp. 707-715, 2005.

10. J. K. Gilbert, R. Justi, and A. S. Queiroz, "The use of a model of modelling to develop visualization during the learning of ionic bonding," Contemporary science education research: international perspectives, pp. 43-51, 2010.

11. M. Turgut and R. Nagy-Kondor, "Spatial visualization skills of Hungarian and Turkish prospective mathematics teachers," Jornal Internacional de Estudos em Educação Matemática, vol. 6, 2015.

12. Y. J. Dori and Z. Kaberman, "Assessing high school chemistry students' modeling sub-skills in a computerized molecular modeling learning environment," Instructional Science, vol. 40, pp. 69-91, 2012.

13. I. D. Cherney and D. Voyer, "Development of a spatial activity questionnaire I: Items identification," Sex Roles, vol. 62, pp. 8999, 2010.

14. B. Cantürk-Günhan, M. Turgut, and S. Yllmaz, "Spatial ability of a mathematics teacher: the case of Oya," IBSU Scientific Journal, vol. 3, pp. 151-158, 2009.

15. Z. Akasah and M. Alias, "Bridging the spatial visualisation skills gap through engineering drawing using the whole-to-parts approach," Australasian Journal of Engineering Education, vol. 16, pp. 81-86, 2010.

16. R. Gorska, "Spatial imagination-an overview of the longitudinal research at Cracow University of Technology," Journal for Geometry and Graphics, vol. 9, pp. 201-208, 2005.

17. G. Marunić and V. Glažar, "Improvement and assessment of spatial ability in engineering education," Engineering Review: Međunarodni časopis namijenjen publiciranju originalnih istraživanja s aspekta analize konstrukcija, materijala i novih tehnologija u području strojarstva, brodogradnje, temeljnih tehničkih znanosti, elektrotehnike, računarstva i građevinarstva, vol. 34, pp. 139-150, 2014.

18. S. Glick, D. Porter, and C. Smith, "Student visualization: Using 3-D models in undergraduate construction management education," International Journal of Construction Education and Research, vol. 8, pp. 26-46, 2012. 
19. D. Blasko and K. Holliday-Darr, "Longitudinal analysis of spatial skills training in engineering graphics," in Proceedings of the 65th Midyear Meeting of the Engineering Design Graphics Division, 2010, pp. 138-151.

20. Y. Dong, "Lessons Learned in Engaging Engineering Students by Improving Their Spatial Visualization Skills, " in American Society for Engineering Education, 2012.

21. S. A. Sorby, "Developing 3D spatial skills for engineering students," Australasian Journal of Engineering Education, vol. 13, pp. 1-11, 2007.

22. H. B. Gerson, S. A. Sorby, A. Wysocki, and B. J. Baartmans, "The development and assessment of multimedia software for improving 3-D spatial visualization skills, " Computer Applications in Engineering Education, vol. 9, pp. 105-113, 2001.

23. S. Olkun, "Making connections: Improving spatial abilities with engineering drawing activities," International Journal of Mathematics Teaching and Learning, vol. 3, pp. 1-10, 2003.

24. H.-C. Wang, C.-Y. Chang, and T.-Y. Li, "The comparative efficacy of 2D-versus 3D-based media design for influencing spatial visualization skills," Computers in Human Behavior, vol. 23, pp. 1943-1957, 2007.

25. S. Hsi, M. C. Linn, and J. E. Bell, "The role of spatial reasoning in engineering and the design of spatial instruction," Journal of engineering education, vol. 86, pp. 151-158, 1997.

26. [26] S. A. Sorby and B. J. Baartmans, "Improving The 3 D Spatial Visualization Skills Of Women Engineering Students," in 1996 Annual Conference, 1996, pp. 1.251. 1-1.251. 5.

27. S. K. Esche, "Integration of Augmented Reality into the CAD Process," age, vol. 23, p. 1.

28. S. A. Sorby, "Developing 3-D spatial visualization skills," Engineering Design Graphics Journal, vol. 63, 2009.

29. D. H. Uttal, N. G. Meadow, E. Tipton, L. L. Hand, A. R. Alden, C. Warren, et al., "The malleability of spatial skills: A metaanalysis of training studies," Psychological bulletin, vol. 139, p. 352, 2013.

30. O. O. Adebayo, E. J. Farrar, R. Evans, T. L. McCray, and T. Nathans-Kelly, "Empowering early mastery of spatial visualization skills in under represented minority engineering students, " in Frontiers in Education Conference (FIE), 2014 IEEE, 2014, pp. $1-8$.

31. E. J. Farrar, F. O. Adebayo, T. L. McCray, T. Nathans-Kelly, and R. Evans, "Learning Spatial Visualization: Beyond Drills and into Early Mastery," Classroom Research Working Paper Series, p. 30.

32. S. A. Sorby and B. J. Baartmans, "The development and assessment of a course for enhancing the 3-D spatial visualization skills of first year engineering students," Journal of Engineering Education, vol. 89, pp. 301-307, 2000.

33. M. Garmendia, J. Guisasola, and E. Sierra, "First-year engineering students' difficulties in visualization and drawing tasks," European Journal of Engineering Education, vol. 32, pp. 315-323, 2007.

34. E. Fouh, M. Akbar, and C. A. Shaffer, "The role of visualization in computer science education," Computers in the Schools, vol. 29, pp. 95-117, 2012.

35. J. Martín-Gutiérrez, M. Contero, and M. Alcañiz, "Augmented reality to training spatial skills, "Procedia Computer Science, vol. 77, pp. 33-39, 2015.

36. K. A. Samsudin, A. Rafi, and A. S. Hanif, "Training in Mental Rotation and Spatial Visualization and Its Impact on Orthographic Drawing Performance," Educational Technology \& Society, vol. 14, pp. 179-186, 2011.

37. C. W. Ferguson, A. Ball, W. McDaniel, and R. Anderson, A comparison of instructional methods for improving the spatialvisualization ability of freshman technology seminar students: Western Carolina University, 2008. 
38. M. Contero, F. Naya, P. Company, J. L. Saorín, and J. Conesa, "Improving visualization skills in engineering education," IEEE Computer Graphics and Applications, vol. 25, pp. 24-31, 2005.

39. C.-H. Ho, C. Eastman, and R. Catrambone, "An investigation of 2D and 3D spatial and mathematical abilities," Design Studies, vol. 27, pp. 505-524, 2006.

40. J. Martín-Gutiérrez, J. L. Saorín, M. Contero, M. Alcañiz, D. C. Pérez-López, and M. Ortega, "Design and validation of an augmented book for spatial abilities development in engineering students, " Computers \& Graphics, vol. 34, pp. 77-91, 2010.

41. S. A. Scribner and M. A. Anderson, "Novice Drafters' Spatial Visualization Development: Influence of Instructional Methods and Individual Learning Styles, "Journal of Industrial Teacher Education, vol. 42, pp. 38-60, 2005.

42. N. Martín-Dorta, J. L. Saorín, and M. Contero, "Development of a fast remedial course to improve the spatial abilities of engineering students," Journal of Engineering Education, vol. 97, pp. 505-513, 2008.

43. J. K. Gilbert, "Visualization: A metacognitive skill in science and science education," in Visualization in science education, ed: Springer, 2005, pp. 9-27.

44. T. Branoff and M. Dobelis, "The relationship between spatial visualization ability and students' ability to model $3 D$ objects from engineering assembly drawings," Engineering Design Graphics Journal, vol. 76, 2013.

45. H. K. Ault and S. John, "Assessing and enhancing visualization skills of engineering students in Africa: A comparative study," Engineering Design Graphics Journal, vol. 74, 2010.

46. J. Yue, "Spatial visualization by realistic 3D views," Engineering Design Graphics Journal, vol. 72, 2009.

47. P. E. Connolly, "Spatial ability improvement and curriculum content," Engineering Design Graphics Journal, vol. 73, 2009.

48. C.-H. Tsai and J.-C. Yen, "The development and evaluation of a Kinect sensor assisted learning system on the spatial visualization skills," Procedia-Social and Behavioral Sciences, vol. 103, pp. 991-998, 2013.

49. P. Connolly and M. sadowski, "ac 2009-363: measuring and enhancing spatial visualization in engineering technology students," age, vol. 14, p. 1, 2009.

50. C. A. Cohen and M. Hegarty, "Inferring cross sections of $3 D$ objects: A new spatial thinking test," Learning and Individual Differences, vol. 22, pp. 868-874, 2012.

51. J. Martín-Gutiérrez, R. E. Navarro, and M. A. González, "Mixed reality for development of spatial skills of first-year engineering students," in Frontiers in Education Conference (FIE), 2011, 2011, pp. T2D-1-T2D-6.

52. J. T. Richards, C. M. Oman, W. L. Shebilske, A. C. Beall, A. Liu, and A. Natapoff, "Training, transfer, and retention of threedimensional spatial memory in virtual environments, "Journal of Vestibular Research, vol. 12, pp. 223-238, 2002.

53. B. Sriraman, P. Ernest, and B. Greer, Critical issues in mathematics education: IAP, 2009.

54. P. Katsioloudis, V. Jovanovic, and M. Jones, "A Comparative Analysis of Spatial Visualization Ability and Drafting Models for Industrial and Technology Education Students," Journal of Technology Education, vol. 26, pp. 88-101, 2014.

55. J. Yue and D. M. Chen, "Does CAD improve spatial visualization ability?," age, vol. 6, p. 1, 2001.

56. T. Thornton, J. V. Ernst, and A. C. Clark, "Augmented reality as a visual and spatial learning tool in technology education," Technology and Engineering Teacher, vol. 71, pp. 18-21, 2012.

57. R. A. Górska, "Investigation of the measures and means for the development of spatial skills, "Journal Biuletyn of Polish Society for Geometry and Engineering Graphics, vol. 15, 2005. 
58. L. T. David, "Training effects on mental rotation, spatial orientation and spatial visualisation depending on the initial level of spatial abilities," Procedia-Social and Behavioral Sciences, vol. 33, pp. 328-332, 2012.

59. A. C. Neubauer, S. Bergner, and M. Schatz, "Two-vs. three-dimensional presentation of mental rotation tasks: Sex differences and effects of training on performance and brain activation, "Intelligence, vol. 38, pp. 529-539, 2010.

60. A. Dünser, K. Steinbügl, H. Kaufmann, and J. Glück, "Virtual and augmented reality as spatial ability training tools," in Proceedings of the 7th ACM SIGCHI New Zealand chapter's international conference on Computer-human interaction: design centered HCI, 2006, pp. 125-132.

61. I. Chester, "3D-CAD: modern technology-outdated pedagogy?," Design and Technology Education: an International Journal, vol. 12, 2008.

62. K. J. Schönborn and T. R. Anderson, "Bridging the educational research-teaching practice gap," Biochemistry and molecular biology education, vol. 38, pp. 347-354, 2010.

63. R. A. Górska and Z. Juscakova, "A pilot study of a new testing method for spatial abilities evaluation," Journal for Geometry and Graphics, vol. 7, pp. 237-246, 2003.

64. G. Sharma and R. Dumpala, "Teaching of mechanical engineering concepts through three-dimensional geometric modeling," International Journal of Mechanical Engineering Education, vol. 43, pp. 180-190, 2015.

65. D. S. Koch, "The effects of solid modeling and visualization on technical problem solving," Virginia Tech, 2006.

66. R. E. Downing, J. L. Moore, and S. W. Brown, "The effects and interaction of spatial visualization and domain expertise on information seeking," Computers in Human Behavior, vol. 21, pp. 195-209, 2005.

67. C. M. Oman, W. L. Shebilske, J. T. Richards, T. C. Tubré, A. C. Beall, and A. Natapoff, "Three dimensional spatial memory and learning in real and virtual environments, "Spatial Cognition and computation, vol. 2, pp. 355-372, 2000.

68. H. King, "Understanding spatial literacy: cognitive and curriculum perspectives, " Planet, vol. 17, pp. 26-28, 2006.

69. A. R. Teyseyre and M. R. Campo, "An overview of 3D software visualization," IEEE Trans. Vis. Comput. Graph., vol. 15, pp. 87-105, 2009.

70. G. Sharma, P. S. Rao, and B. S. Babu, "A Spatial Visualization Methodology in Brainstorming the Causal Factors for Process Deviations in Manufacturing," 2016.

71. C. Van der Lelie, "The value of storyboards in the product design process," Personal and ubiquitous computing, vol. 10, pp. 159-162, 2006.

72. J. Herter, R. Brown, and J. Ovtcharova, "A visual language for the collaborative visualization of integrated conceptual models in product development scenarios, " in Smart Product Engineering, ed: Springer, 2013, pp. 805-814.

73. J. Shah, J. Woodward, and S. Smith, "Development of standardized tests for design skills," in DS 58-10: Proceedings of ICED 09, the 17th International Conference on Engineering Design, Vol. 10, Design Education and Lifelong Learning, Palo Alto, CA, USA, 24.-27.08. 2009, 2009, pp. 269-280.

74. K. R. Wanzel, S. J. Hamstra, M. F. Caminiti, D. J. Anastakis, E. D. Grober, and R. K. Reznick, "Visual-spatial ability correlates with efficiency of hand motion and successful surgical performance," Surgery, vol. 134, pp. 750-757, 2003.

75. M. G. Jones and B. Broadwell, "Visualization Without Vision: Students with Visual," in Visualization: Theory and practice in science education, ed: Springer, 2008, pp. 283-294.

76. D. Passig and S. Eden, "Enhancing the induction skill of deaf and hard-of-hearing children with virtual reality technology," 
Journal of Deaf Studies and Deaf Education, vol. 5, pp. 277-285, 2000.

77. D. N. Brewer, T. D. Wilson, R. Eagleson, and S. de Ribaupierre, "Evaluation of neuroanatomical training using a $3 d$ visual reality model," in MMVR, 2012, pp. 85-91.

78. M. Reinhard Friedl, "Virtual reality and 3D visualizations in heart surgery education," in The Heart surgery forum, 2002, p. 03054.

79. C. Silén, S. Wirell, J. Kvist, E. Nylander, and Ö. Smedby, "Advanced 3D visualization in student-centred medical education," Medical teacher, vol. 30, pp. e115-e124, 2008.

80. M. Keehner, Y. Lippa, D. R. Montello, F. Tendick, and M. Hegarty, "Learning a spatial skill for surgery: How the contributions of abilities change with practice," Applied Cognitive Psychology: The Official Journal of the Society for Applied Research in Memory and Cognition, vol. 20, pp. 487-503, 2006.

81. N. Nguyen, A. J. Nelson, and T. D. Wilson, "Computer visualizations: Factors that influence spatial anatomy comprehension," Anatomical Sciences Education, vol. 5, pp. 98-108, 2012.

82. H. Petersson, D. Sinkvist, C. Wang, and Ö. Smedby, "Web-based interactive $3 D$ visualization as a tool for improved anatomy learning, "Anatomical sciences education, vol. 2, pp. 61-68, 2009

83. 2Salma Begum, "“Space Vs Place”_Focusing On the Plaza in Front of Building No 9 in Peterbos Social Housing, Brussels, Belgium “, International Journal of Civil Engineering (IJCE), Vol. 7, Issue 1,pp. 1-8

84. Arasinah Kamis, Rosmawati Mamat, Norwati Sapie Safie \& Ramlee Mustapha, "Spatial Visualization Ability Among Apparel Design Students", BEST: International Journal of Humanities, Arts, Medicine and Sciences (BEST: IJHAMS), Vol. 3, Issue 2, pp. $15-24$

85. S. Jayanthi, “Trans Cultural Communication in Amitav Ghosh's the Hungry Tide”, International Journal of Linguistics and Literature (IJLL), Vol. 6, Issue 5,pp. 19-22

86. Seyed Ali Azimi Rashti \& Mehrdad Javaherian, “Exploring the Possibilities of Zoning Techniques in Assuring Urban Quality of Life”, BEST: International Journal of Management, Information Technology and Engineering (BEST: IJMITE), Vol. 4, Issue 2, pp. $1-18$ 